International Journal of Advanced Chemistry, $8(1)(2020) 6-14$
International Journal of Advanced Chemistry
SPC
Website: www.sciencepubco.com/index.php/IJAC
Research paper

\title{
Evaluation of essential and heavy metal levels in pasteurized and long-life cow milk
}

\author{
Mohamed Atiga Elbagermi ${ }^{1}$, Antisar Abdulmajid Bin Haleem ${ }^{1}$, Khaled Muftah Elsherif ${ }^{2 *}$ \\ ${ }^{1}$ Chemistry Department, Faculty of Science, Misurata University, Misurata-Libya \\ ${ }^{2}$ Chemistry Department, Faculty of Science, University of Benghazi, Benghazi-Libya \\ *Corresponding author E-mail: elsherif27@yahoo.com
}

\begin{abstract}
In the present investigation, 11 cow's milk samples (pasteurized and long life) were collected from supermarkets in Misurata city, Libya. For the determination of metal contents, the milk samples were subjected to the optimized microwave digestion method using $\mathrm{HNO}_{3}$ and $\mathrm{H}_{2} \mathrm{O}_{2}$. The levels of $\mathrm{Na}, \mathrm{K}, \mathrm{Mg}, \mathrm{Ca}, \mathrm{Fe}, \mathrm{Cu}, \mathrm{Cr}, \mathrm{Mn}, \mathrm{Co}, \mathrm{Ni}, \mathrm{Zn}, \mathrm{Cd}$, and $\mathrm{Pb}$ were evaluated by Microwave Plasma - Atomic Emission Spectrophotometer (MP-AES 4100). It was found that potassium is the most concentrated essential metal while zinc is the highest detected heavy metal in all milk samples. The levels of $\mathrm{Co}$ and $\mathrm{Cd}$ were not detected in all milk samples under investigation (lower than instrumental detection limits). The mean concentrations of the detected metals were as follows: $828.05 \pm 0.82,587.57 \pm 0.87,512.38 \pm 0.30$, $73.79 \pm 0.19,2.014 \pm 0.19,1.89 \pm 0.16,0.178 \pm 0.03,0.061 \pm 0.02,0.074 \pm 0.01,0.053 \pm 0.001$, and $0.045 \pm 0.001$ for: $\mathrm{K}, \mathrm{Ca}, \mathrm{Na}, \mathrm{Mg}, \mathrm{Zn}, \mathrm{Fe}, \mathrm{Cu}$, $\mathrm{Mn}, \mathrm{Ni}, \mathrm{Pb}$, and $\mathrm{Cr}$ ppm, respectively. There is no significant difference in the mean concentrations of $\mathrm{Ni}, \mathrm{Cr}$ and $\mathrm{Pb}$ between the investigated milk samples. Though, the levels of essential and heavy metals observed were similar with other reported values in the literature.
\end{abstract}

Keywords: Pasteurized Milk; Long Life Milk; Essential Metals; Heavy Metals.

\section{Introduction}

To monitor and support products and methods quality, good feature determinations are essential, both in manufacture, business, and in research. Also, the increasing significance of chemical measurements has impressively forced the enlargement of procedures to enhance the quality of analytical results and to assurance quality to the end consumers [Kira \& Maihara 2007].

Heavy metals are incessant chemical pollutants in the world that can produce critical environmental and health risks. They are discharged into the ecosystem from the natural in addition to anthropogenic activities [Abdulkhaliq et al. 2012]. Certain heavy metals like Fe, Zn, $\mathrm{Co}$ and $\mathrm{Cu}$ are needed to continue suitable metabolic performance in living organisms; others such as $\mathrm{Hg}, \mathrm{Pb}, \mathrm{As}$ and $\mathrm{Cd}$ are unnecessary and have no biological function [Khan et al. 2013]. Nevertheless, at extreme levels, both types cause toxicity to living organisms [Belete et al. 2014].

The presence of heavy metals in milk and dairy products is due to subject of the animals to particular circumstances such as consuming pasture or drinking water from polluted resources. Still, heavy metal quantities in the milk be influenced by the level of exposure of the animal to the contaminated position [Amponsah 2014]. The virtually prevalent existence of certain metal contaminants, particularly Pb, $\mathrm{Cd}, \mathrm{Hg}$ and $\mathrm{Ni}$, enables their access into the food chain and consequently enhances the opportunity of them having toxic influences on people and animals. Even though heavy metals have industrial benefits, their probable toxicity for human and animals is the target of numerous researches. For specific elements, the influences are accumulative and it is required to monitor their levels in consumed food [Elsherif et al. 2017].

Several studies denote the existence of heavy metals in milk and dairy products, and frequently it is required to evaluate the levels of them in food. Cadmium, mercury, and lead remains in milk are of specific interest since milk is mostly consumed by infants and children [Tajkarimi et al. 2008], and the estimation of these metals quantities in milk is especially attended by international organizations.

For performing these estimations, several techniques were utilized such as flame and flameless atomic absorption spectrometry (FAAS and ETAAS), inductively coupled plasma optical emission spectrometry (ICP-OES), inductively coupled plasma mass spectrometry (ICP-MS), flow injection spectrometry (FIS), fluorescence atomic spectrometry (FAS), capillary zone electrophoresis (CZE), differential pulse anodic stripping voltammetry (DPASV), atomic and stripping potentiometry (ASP) [Cava-Montesinos et al. 2004, Suarez-Luque et al. 2007, Elsherif et al 2012a; 2012b; 2013, 2015].

The purpose of the present work is to evaluate the concentrations of major metals ( $\mathrm{Na}, \mathrm{K}, \mathrm{Ca}$, and $\mathrm{Mg}$ ) and heavy metals $(\mathrm{Fe}, \mathrm{Cu}, \mathrm{Zn}, \mathrm{Co}$, $\mathrm{Ni}, \mathrm{Cr}, \mathrm{Pb}, \mathrm{Cd}$, and $\mathrm{Mn}$ ) in eleven long life and pasteurized milk samples available in Misurata city markets and to find out whether the levels of these metals are lower or higher than the recommended concentrations demanded for human consumption; particularly children, and furthermore to attain the extent of contamination. 


\section{Materials and methods}

\subsection{Milk samples collection}

In the present investigation, the commercially available pasteurized and long life cow's milk samples were purchased from several supermarkets in Misurata city. A one liter of milk product was obtained for each sample. The milk samples of various types examined in the present study are coded and listed in Tables 1 .

Table 1: The Type and Code of the Examined Milk Samples

\begin{tabular}{ll}
\hline Product type & Symbol \\
\hline Rayhan full milk & U1 \\
Sohoul full milk & U2 \\
Zahrat full milk & U3 \\
Rabie full milk & $\mathrm{U} 4$ \\
Juhayna full milk & $\mathrm{U} 5$ \\
Candia full milk & $\mathrm{U} 6$ \\
Rayhan skimmed milk & $\mathrm{U} 7$ \\
Juhayna skimmed milk & $\mathrm{U} 8$ \\
Rawi pasteurized milk & $\mathrm{P} 1$ \\
Al Mazraa pasteurized milk & \\
Raw Local milk & $\mathrm{P} 1$ \\
\hline
\end{tabular}

*U: long life milk, P: pasteurized milk, R: raw milk.

\subsection{Milk sample digestion and analysis}

The best microwave digestion method was chosen according to the clearness of digests, nominal digestion program, and smallest reagent amount, ease and lower heating temperature. A $3.0 \mathrm{~g}$ of each milk sample was placed in $60 \mathrm{~mL}$ Teflon digestion vessel and then volumes of $8 \mathrm{~mL}$ of $70 \%$ nitric acid and $2 \mathrm{~mL}$ of $30 \%$ hydrogen peroxide were added. The mixture was after that shaken thoroughly and kept for 10 min before closing the vessel. The samples were exposed to the optimized microwave digestion program (MARS6 Microwave Digestion-CEM) for 2 hours at temperatures between $25-170^{\circ} \mathrm{C}$. After completion the heating program, the sample was cooled to room temperature and then digestion vessels were opened carefully in a fume hood. The digest was transferred into $50 \mathrm{~mL}$ volumetric flask and completed to the mark with deionized water. Digestion of reagent blank was similarly done in the same manner as milk samples. The metal concentrations in the digested milk samples were estimated using microwave plasma - atomic emission spectrophotometer (MPAES 4100) from Agilent - USA.

\subsection{Reagents and glass wares}

Standard solutions of $\mathrm{Na}, \mathrm{K}, \mathrm{Ca}, \mathrm{Mg}, \mathrm{Fe}, \mathrm{Zn}, \mathrm{Mn}, \mathrm{Ni}, \mathrm{Co}, \mathrm{Cd}, \mathrm{Cr}, \mathrm{Cu}$, and $\mathrm{Pb}$ designed for atomic absorption spectroscopy were bought from Fisher Scientific Company, USA and used for preparing working standard solutions by diluting the stock solution. Nitric acid and hydrogen peroxide were of AR quality (BDH, England). All glass wares (pipette, volumetric flask, measuring cylinder, etc.) were washed before use with deionized water, soaked in nitric acid $(10 \%)$, then rinsed with deionized water and finally air dried. The glass ware kept in clean place, to avoid contamination.

\section{Results and discussion}

The findings of our investigation for 13 elements in 11 milk samples (pasteurized and long life) which were from different brands are provided in Tables 2 and 3. The major metals concentrations in cow's milk samples are given in Table 2, while the heavy metals levels are displayed in Table 3.

Table 2: Major Metal Concentrations in Cow's Milk Samples

\begin{tabular}{lllll}
\hline \multicolumn{5}{c}{ Table 2: Major Metal Concentrations in Cow's Milk Samples } \\
\hline Sample & $\mathrm{Mg}$ & $\mathrm{Ca}$ & $\mathrm{K}$ & $\mathrm{Na}$ \\
\hline U1 & $61.96 \pm 0.32$ & $562.7 \pm 0.98$ & $798.7 \pm 0.72$ & $462.9 \pm 0.22$ \\
U2 & $60.95 \pm 0.22$ & $518.4 \pm 0.78$ & $793.8 \pm 0.63$ & $620.3 \pm 0.25$ \\
U3 & $72.93 \pm 0.14$ & $632.7 \pm 0.74$ & $861.7 \pm 0.62$ & $571.4 \pm 0.52$ \\
U4 & $71.41 \pm 0.12$ & $526.9 \pm 0.72$ & $769.6 \pm 0.83$ & $489.5 \pm 0.16$ \\
U5 & $80.44 \pm 0.12$ & $583.8 \pm 1.12$ & $898.4 \pm 0.84$ & $512.5 \pm 0.55$ \\
U6 & $80.19 \pm 0.32$ & $544.6 \pm 0.73$ & $894.7 \pm 0.94$ & $514.3 \pm 0.23$ \\
U7 & $80.23 \pm 0.17$ & $563.7 \pm 1.23$ & $901.6 \pm 0.93$ & $350.4 \pm 0.21$ \\
U8 & $73.76 \pm 0.17$ & $638.9 \pm 0.93$ & $827.8 \pm 0.82$ & $556.5 \pm 0.31$ \\
P1 & $73.64 \pm 0.12$ & $597.3 \pm 0.89$ & $852.9 \pm 1.13$ & $554.3 \pm 0.36$ \\
P2 & $80.27 \pm 0.15$ & $611.6 \pm 0.78$ & $893.7 \pm 0.78$ & $439.4 \pm 0.42$ \\
R1 & $75.92 \pm 0.25$ & $682.7 \pm 0.68$ & $885.7 \pm 0.81$ & $512.38 \pm 0.30$ \\
Mean & $73.79 \pm 0.19$ & $587.57 \pm 0.87$ & $828.05 \pm 0.82$ & \\
\hline
\end{tabular}

Table 3: Heavy Metal Concentrations in Cow's Milk Samples

\begin{tabular}{|c|c|c|c|c|c|c|c|c|c|c|}
\hline Sample & Results & $\mathrm{Co}$ & $\mathrm{Cd}$ & $\mathrm{Pb}$ & $\mathrm{Cr}$ & $\mathrm{Zn}$ & $\mathrm{Ni}$ & $\mathrm{Mn}$ & $\mathrm{Cu}$ & $\mathrm{Fe}$ \\
\hline \multirow[t]{2}{*}{ U1 } & Mean & ND & ND & 0.062 & 0.036 & 2.53 & 0.061 & 0.089 & 0.147 & 1.23 \\
\hline & $\mathrm{SD} \pm$ & - & - & 0.001 & 0.001 & 0.13 & 0.01 & 0.01 & 0.04 & 0.12 \\
\hline $\mathrm{U} 2$ & Mean & ND & ND & 0.064 & 0.032 & 1.54 & 0.052 & 0.017 & 0.155 & 1.26 \\
\hline \multirow[t]{2}{*}{ U3 } & Mean & ND & ND & 0.083 & 0.021 & 1.24 & 0.087 & 0.04 & 0.165 & 2.18 \\
\hline & $\mathrm{SD} \pm$ & - & - & 0.001 & 0.001 & 0.12 & 0.01 & 0.02 & 0.06 & 0.14 \\
\hline \multirow[t]{2}{*}{ U4 } & Mean & ND & ND & 0.071 & 0.042 & 1.86 & 0.097 & 0.051 & 0.174 & 1.12 \\
\hline & $\mathrm{SD} \pm$ & - & - & 0.001 & 0.001 & 0.32 & 0.02 & 0.01 & 0.02 & 0.16 \\
\hline
\end{tabular}




\begin{tabular}{|c|c|c|c|c|c|c|c|c|c|c|}
\hline \multirow[t]{2}{*}{ U5 } & Mean & ND & ND & 0.031 & 0.062 & 2.34 & 0.068 & 0.032 & 0.148 & 1.87 \\
\hline & $\mathrm{SD} \pm$ & - & - & 0.001 & 0.001 & 0.08 & 0.01 & 0.01 & 0.04 & 0.12 \\
\hline \multirow[t]{2}{*}{ U6 } & Mean & ND & ND & 0.061 & 0.083 & 2.31 & 0.058 & 0.089 & 0.188 & 1.11 \\
\hline & $\mathrm{SD} \pm$ & - & - & 0.001 & 0.001 & 0.17 & 0.01 & 0.01 & 0.01 & 0.22 \\
\hline \multirow[t]{2}{*}{ U7 } & Mean & ND & ND & 0.053 & 0.040 & 2.11 & 0.095 & 0.067 & 0.164 & 4.33 \\
\hline & $\mathrm{SD} \pm$ & - & - & 0.001 & 0.001 & 0.11 & 0.01 & 0.02 & 0.01 & 0.14 \\
\hline \multirow[t]{2}{*}{ U8 } & Mean & ND & ND & 0.051 & 0.061 & 2.23 & 0.057 & 0.097 & 0.163 & 2.17 \\
\hline & $\mathrm{SD} \pm$ & - & - & 0.001 & 0.001 & 0.35 & 0.02 & 0.01 & 0.02 & 0.11 \\
\hline \multirow[t]{2}{*}{$\mathrm{P} 1$} & Mean & ND & ND & 0.043 & 0.033 & 2.03 & 0.096 & 0.044 & 0.185 & 1.68 \\
\hline & $\mathrm{SD} \pm$ & - & - & 0.001 & 0.001 & 0.25 & 0.01 & 0.01 & 0.02 & 0.2 \\
\hline \multirow[t]{2}{*}{$\mathrm{P} 2$} & Mean & ND & ND & 0.032 & 0.05 & 1.98 & 0.086 & 0.056 & 0.165 & 1.57 \\
\hline & $\mathrm{SD} \pm$ & - & - & 0.001 & 0.001 & 0.18 & 0.03 & 0.03 & 0.04 & 0.23 \\
\hline \multirow[t]{2}{*}{ R1 } & Mean & ND & ND & 0.024 & 0.031 & 1.98 & 0.054 & 0.092 & 0.305 & 2.32 \\
\hline & $\mathrm{SD} \pm$ & - & - & 0.001 & 0.001 & 0.18 & 0.02 & 0.01 & 0.01 & 0.13 \\
\hline \multirow{2}{*}{ Mean } & & - & & 0.053 & 0.045 & 2.014 & 0.074 & 0.061 & 0.178 & 1.89 \\
\hline & & - & - & \pm 0.001 & \pm 0.001 & \pm 0.19 & \pm 0.01 & \pm 0.02 & \pm 0.03 & \pm 0.16 \\
\hline
\end{tabular}

ND: Not Detected (under detection limits).

For major metals in milk samples, the mean concentration of $\mathrm{K}$ was the highest $(828.05 \pm 0.82 \mathrm{ppm})$ followed by Ca $(587.57 \pm 0.87 \mathrm{ppm})$, $\mathrm{Na}(512.38 \pm 0.30 \mathrm{ppm})$, and the last one was $\mathrm{Mg}(73.79 \pm 0.19 \mathrm{ppm})$. The trend for heavy metals observed for milk samples were as follows: $\mathrm{Zn}(2.014 \pm 0.19 \mathrm{ppm}) \sim \mathrm{Fe}(1.89 \pm 0.16 \mathrm{ppm}), \mathrm{Cu}(0.178 \pm 0.03 \mathrm{ppm}), \mathrm{Ni}(0.074 \pm 0.01 \mathrm{ppm}) \sim \mathrm{Mn}(0.61 \pm 0.02 \mathrm{ppm})$, and finally $\mathrm{Pb}(0.053 \pm 0.001 \mathrm{ppm}) \sim \mathrm{Cr}(0.045 \pm 0.001 \mathrm{ppm})$. The Co and $\mathrm{Cd}$ concentrations were lower the instrument detection limits in all examined milk samples. From the detected heavy metals, the highest mean concentration obtained was for $\mathrm{Zn}$ which is similar to Belete et. al. (2014) and Farid et. al. (2004) findings.

\subsection{Sodium levels}

In Fig. 1, the sodium levels for milk samples under investigation are shown which ranged from 350.4 to 624.6 ppm. Though, there are no limits for sodium levels specified by the Libyan standard specifications for milk samples but our results were similar to those reported by Qin et al. (361 - 571 ppm) (2009), Gabryszuk et al. (357 - 490 ppm) (2008), and Gaucheron (391 - 644 ppm) (2005). Sodium (Na) consumption should be examined in young children because their excretory system is less effective to eliminate Na than that of adults (Michaelsen et al. 2000). Accordingly, extra sodium may cause in early health difficulties for the young children, along with influencing their long-term health condition. While Na sources may vary over time, indications propose that main sources of nutritional Na for primary school children aged 4-13 years are processed food like meat and poultry products, cereal and cereal products, and milk products. Whole milk, powder milk, flavoured milk, diary milk products provides the most sodium (Marcio et al. 2016).



Fig. 1: Sodium Contents in Milk Samples.

\subsection{Potassium levels}

As shown in Fig. 2, it is observed that potassium contents for investigated milk samples were ranged from $769.6-901.6$ ppm which is related to previous studies, Qin et al. (908 - $117 \mathrm{ppm})(2009)$, Gabryszuk et al. (856 - $978 \mathrm{ppm})(2008)$, and Gaucheron (1212 - 1681 ppm) (2005). Also, there are no limits for potassium levels specified by the Libyan standard specifications for milk samples. Moreover, we observed that $\mathrm{K}$ contents were higher than the other essential minerals. Sodium and potassium levels in the body are $1.4 \mathrm{~g} / \mathrm{kg}$ and 2 $\mathrm{g} / \mathrm{kg}$, respectively. Potassium is the highest widespread cation in the intracellular fluid. It controls the osmotic pressure inside the cell and additionally in the activation of a number of glycolytic and respiratory enzymes. Milk and yogurt, besides nuts, are also excellent sources of potassium (Ateteallah et al. 2017). 


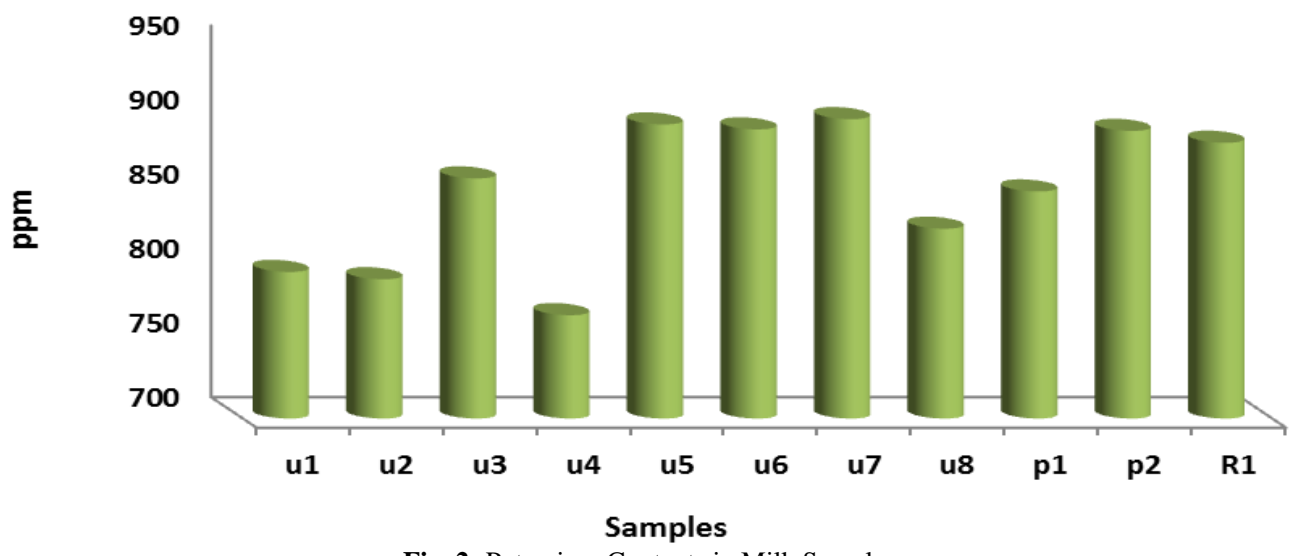

Fig. 2: Potassium Contents in Milk Samples.

\subsection{Calcium levels}

Fig. 3 presents calcium levels for each milk sample. And according to the Table 2., Ca concentrations were in the range of $518.4-682.7$ ppm. The highest concentration of Calcium was found in the sample R1 while the lower concentration was in U2. Generally, The Ca contents of our milk samples were lower than the values reported by other authors $(970-1650 \mathrm{ppm})$ (Cashman et al. 2006, SolaLaranaga et al. 2009). Still, the concentrations of Ca in our milk samples were comparable with those reported by Gabryszuk et al. (567 $706 \mathrm{ppm}$ ) (2008). Calcium is an fundamental macronutrient for humans, which presents about $2 \%$ of human body weight in adults. This mineral has primarily a structural role in bones and teeth, and regulates many essential biological functions. In recent times, the concern in calcium has focused on its role in avoiding osteoporosis. The bioavailability of calcium in milk is thought to be fundamental (Ateteallah et al. 2017).

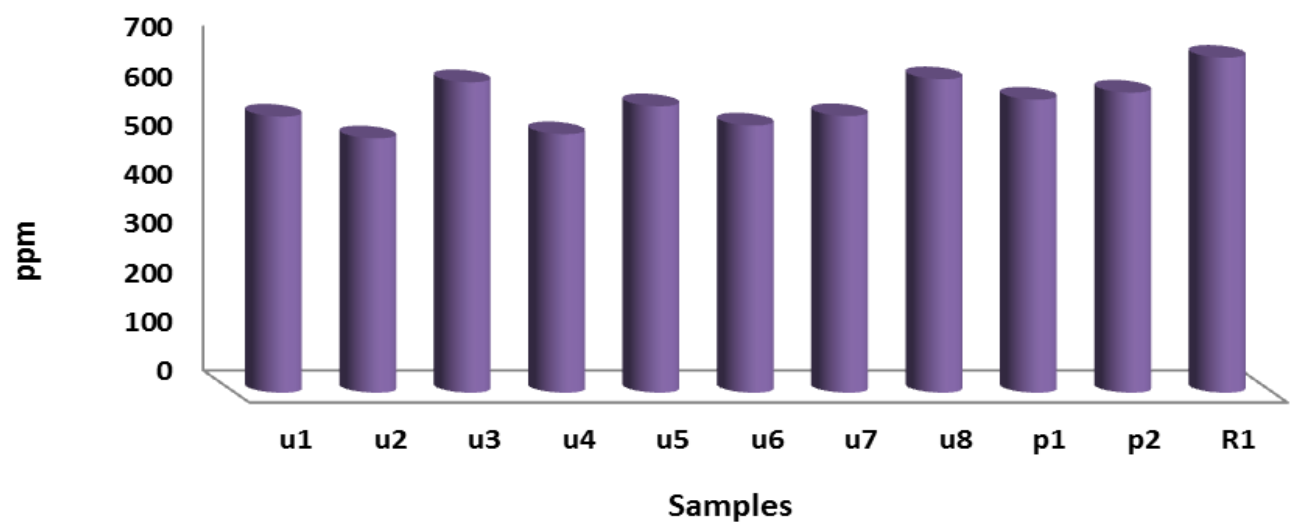

Fig. 3: Calcium Contents in Milk Samples.

\subsection{Magnesium levels}

The Mg levels were ranged from 60.95 to $80.44 \mathrm{ppm}$. The results of $\mathrm{Mg}$ concentrations are displayed in Fig. 4. Concentrations of Mg in our milk samples were compared with other studies. In Qin et al. (2009) study, the concentrations of Mg was ranged between $117-125$ ppm. Malbe et al. (2010) reported that the range of Mg concentrations in milk samples is between 96 - 125 ppm. In Moreno et al. (1994) study, Mg content was in the range of $98-121 \mathrm{ppm}$. Magnesium being a main element involved for the organizing of various body tasks. $\mathrm{Mg}$ Lowers muscle straining, lower pain related to migraine headaches and better sleep \& bad neurological complaint like anxiety and depression. Magnesium is required for above 300 biochemical reactions in the body. It assists to take care of regular nerve and muscle function, maintains a healthy immune system, saves the heart beat stable, and supports bones stay strong. It also aids control blood glucose levels and assists in the creation of energy and protein. Mainly nutritional magnesium originates from vegetables, like dark green, leafy vegetables (Lutfullah et al. 2014).

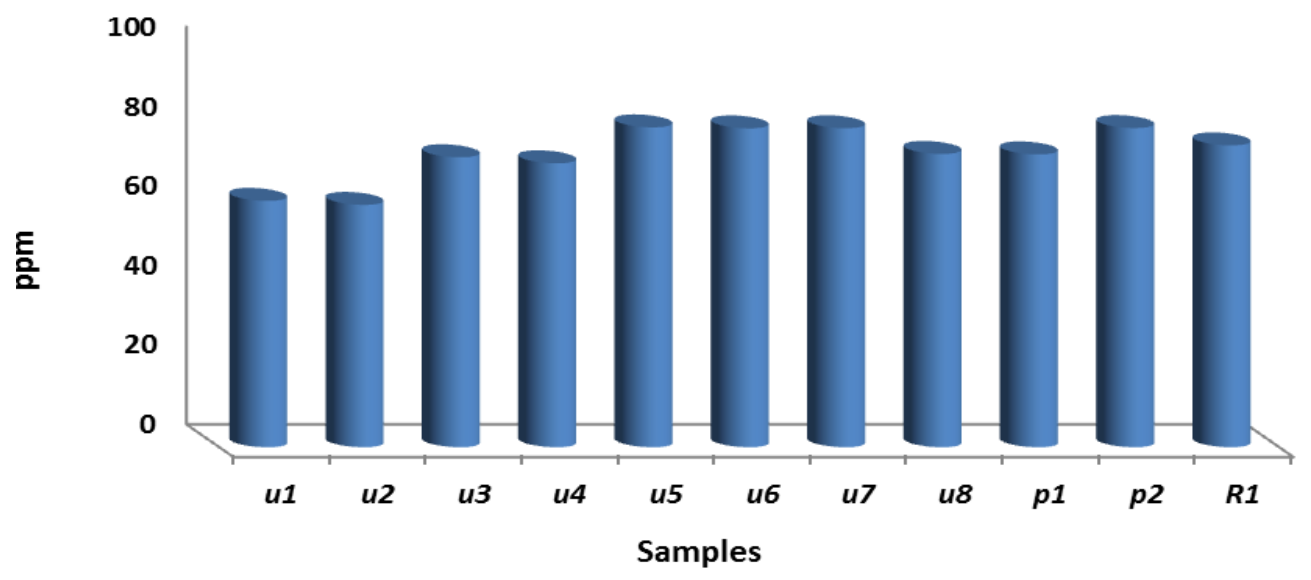


Fig. 4: Magnesium Contents in Milk Samples.

\subsection{Iron levels}

The results of iron levels in the present study are shown in Fig. 5. The Fe concentration in the analyzed milk samples was ranged from 1.11 to $4.33 \mathrm{ppm}$. Though, the present values of Fe concentration is lower than the corresponding values of Malhat et al. (1.84 - 50.00 ppm) (2012). This shows that the cow's milk sample is a poor source of iron. However, our results were comparable with other studies (Qin et al. 2009, Birghila et al. 2008, Ogabiela et al. 2011). Various studies has revealed that consumption of cow's milk in nature constantly play as a risk factor for anemia in children (Hadler et al. 2004, Assis et al. 2004, Oliveira et al. 2005). In the study of Hadler et al. (2004) detected that the consumption of fresh cow's milk had a positive relation with anemia occurrence in children aged 6 to 12 months. The authors describe that an enlarged ingestion of cow's milk, whose iron level is lowered and has minimal bioavailability, can lessen the total amount of iron included in the diet or replacement other probable sources of this nutrient. Improved milk, enhanced with iron, though, decreases the risks of anemia by enhancing the concentration of iron in the milk (Oliveira et al. 2005).

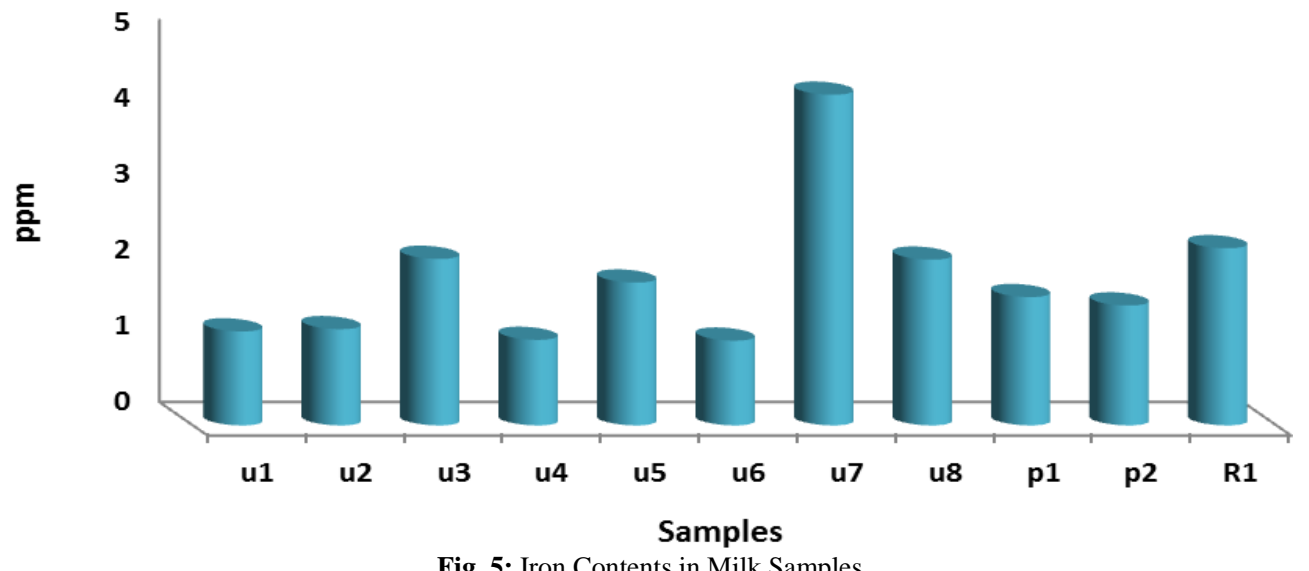

Fig. 5: Iron Contents in Milk Samples.

\subsection{Zinc levels}

The zinc contents in the examined milk samples are presented in Fig. 6 . The results demonstrated that the $\mathrm{Zn}$ contents were in the range of $1.24-2.53 \mathrm{ppm}$ in the milk samples. These concentrations were lower than those determined in previous studies (Lante et al. 2004, Enb et al. 2009). However, Zn levels are in the line with those reported by Onianwa et al. (1999). Ingesting unreasonably extent of zinc into the body through food, water, or dietary complements can influence health. The suggested dietary allowances for zinc is $11 \mathrm{mg} / \mathrm{day}$ for men and $8 \mathrm{mg} /$ day for women. If huge amounts of zinc (10-15 times greater than the suggested) are obtained; even for a short time, stomach cramps, nausea, and vomiting may happen. Feeding elevated levels of zinc for a number of months may initiate anemia, harm the pancreas, and reduce levels of high-density lipoprotein (HDL) cholesterol (National Academies Press (US) 2001).

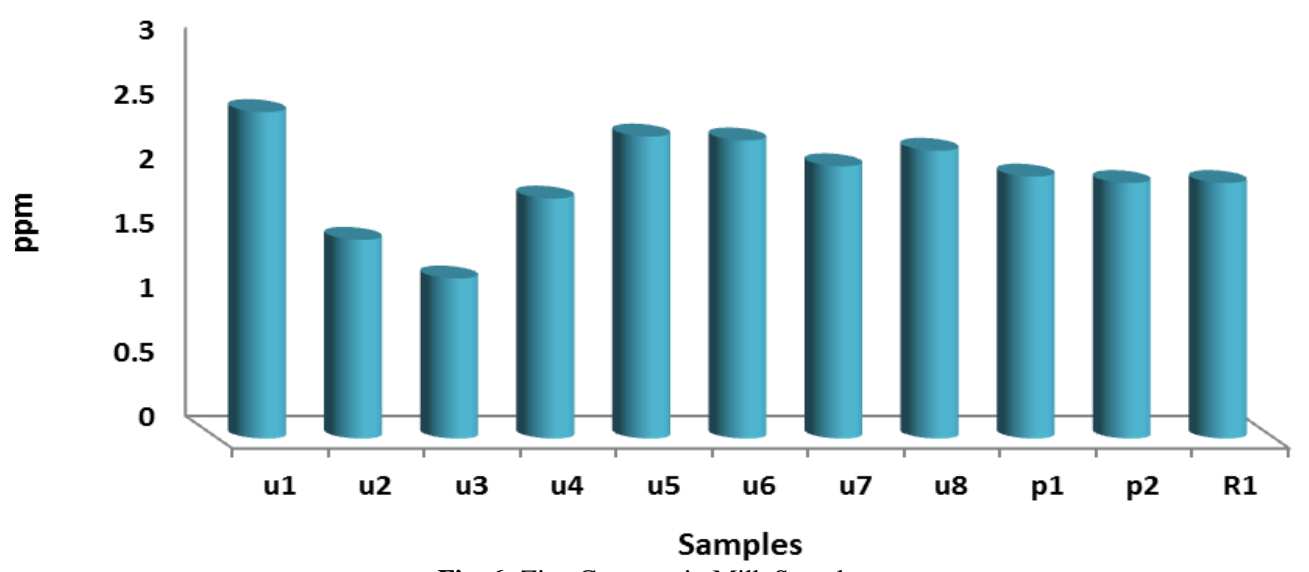

Fig. 6: Zinc Contents in Milk Samples.

\subsection{Copper levels}

As it can be observed from the Fig. 7, the $\mathrm{Cu}$ content found in the cow milk varies in its quantity from 0.305 to $0.147 \mathrm{ppm}$. There are no limits for copper levels specified by the Libyan standard specifications for milk samples. Increased copper levels in milk leads to vitamin $\mathrm{C}$ deficiency and also it is a catalyst for oxidation and fatty taste in milk. Copper poisoning may lead to infections and cancers in the lung and breast (Zheng et al. 2007). Cu levels are in our study were lower than those reported by other authors (Licata et al. 2004, Nasr et al. 2007, Goncalves et al. 2008). The minimal levels of $\mathrm{Cu}$ could be as a result of $\mathrm{Zn}$ included in food that disturbs with the copper absorption system, describing the occurrence of low levels of this metal in milk (Doull's 2000). However, our results were comparable to those reported by Malhat. et al. (2012). 


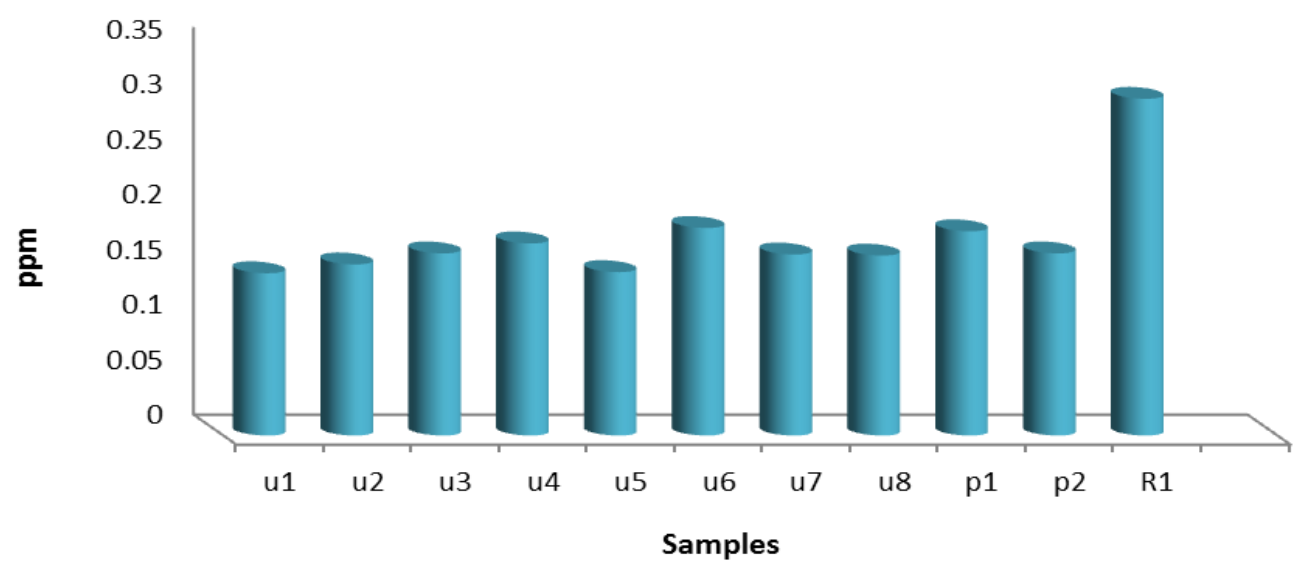

Fig. 7: Copper Contents in Milk Samples.

\subsection{Manganese levels}

Manganese concentrations in the examined milk samples are shown in Fig. 8. Our Mn concentrations in the cow milk samples have ranged from 0.017 to $0.097 \mathrm{ppm}$ with an average of $0.061 \pm 0.02 \mathrm{ppm}$. In Ogabiela et al. study (2011) to estimate the mineral content of fresh milk in Challawa industrial region in Kano Nigeria, the mean manganese concentration was $0.179 \pm 0.13$ ppm while its concentration in the region of Zaria Kaduna had an average of $0.219 \pm 0.09 \mathrm{ppm}$. In the study conducted by Birghila et al. (2008) to estimate the minor and major elements in cow milk, mean manganese concentration in fresh milk was 0.08 ppm while in pasteurized milk was between $0.04-0.09 \mathrm{ppm}$ which were similar to our results. Manganese is an important trace metal that is naturally existing in many foods and offered as a dietary supplement. Manganese is a cofactor for various enzymes, containing manganese superoxide dismutase, arginase, and pyruvate carboxylase. Manganese concentrations are 3 to $10 \mathrm{mcg} / \mathrm{L}$ in breast milk and 30 to $100 \mathrm{mcg} / \mathrm{L}$ in cow's milk-based infant formulas. Soy-based infant formulas have elevated manganese concentrations, 200 to $300 \mathrm{mcg} / \mathrm{L}$, than milk-based formulas (Buchman et al 2014).

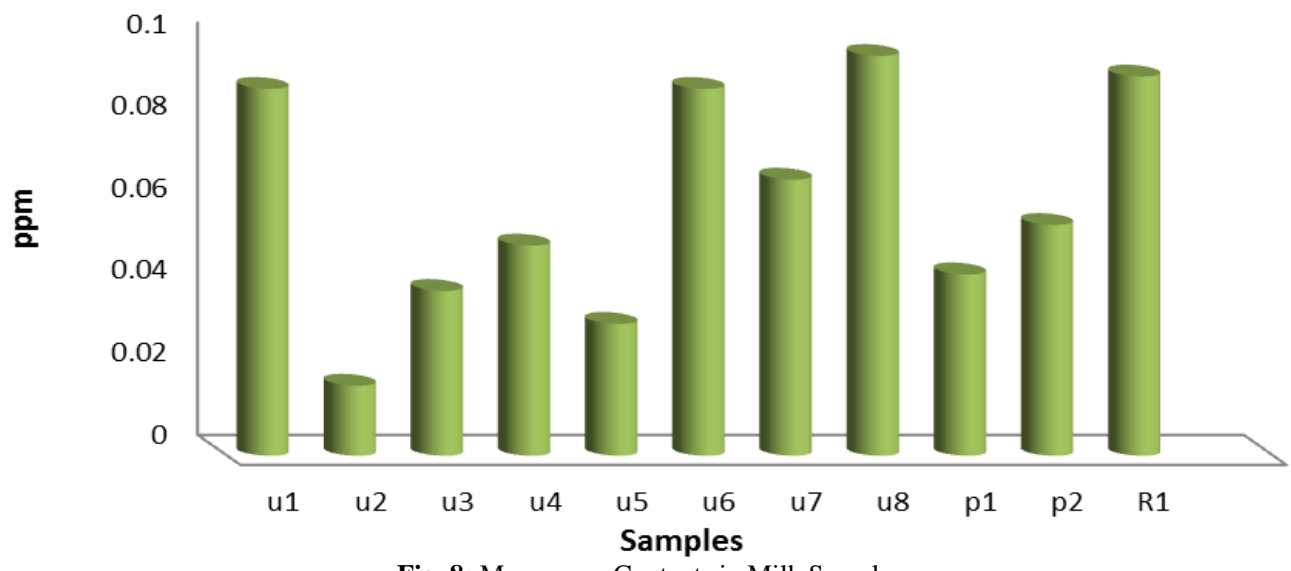

Fig. 8: Manganese Contents in Milk Samples.

\subsection{Nickel levels}

From Fig. 9, we notice that the nickel content in the milk samples ranged from $(0.052-0.097 \mathrm{ppm})$. The lowest level of nickel was in the sample U2 while the highest was detected in the sample U4. In the study conducted by Enb et al. (2009), nickel concentrations in bovine milk samples ranged from (0.002 $-0.009 \mathrm{ppm})$ which were lower than the results found in our current study. While in the Birghila et al. (2008) study to estimate the minor and major elements in milk samples using ICP- AES, the mean Ni concentration in fresh milk was $0.04 \mathrm{ppm}$ whereas in pasteurized milk was $0.04 \mathrm{ppm}$. Nickel is found in both human and cow's milk at levels stated to range from 0.001 to over $0.1 \mathrm{ppm}$, although concentrations in USA studies indicate levels in the region of $0.015 \mathrm{ppm}$ (EU, 2004).

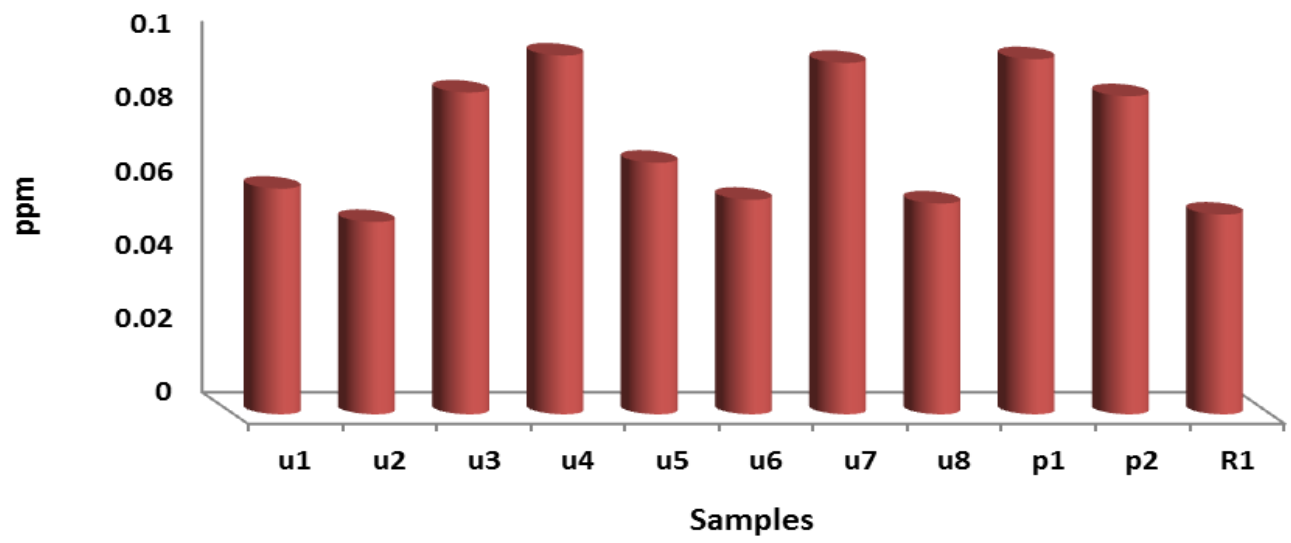


Fig. 9: Nickel Contents in Milk Samples.

\subsection{Chrome levels}

Distribution of $\mathrm{Cr}$ concentrations in the milk samples are depicted in Fig. 10. The mean concentration of $\mathrm{Cr}$ was $0.045 \pm 0.001 \mathrm{ppm}$ (range: $0.021-0.083 \mathrm{ppm}$ ). In Birghila et al. (2008), the Cr levels in fresh and pasteurized milk samples were observed to be similar to our values (0.04 and 0.05 ppm). Whereas in the studies conducted by Enb et al. (2009), Licata et al. (2004), and Flynn (1992), the levels were lower compared to the present study. Though $\mathrm{Cr}$ and other microelements are necessary to continue the metabolic systems of human body, they can cause poisoning at elevated level (Qin et al. 2009). It can initiate stomach upsets and ulcers, convulsions, kidney and liver injury, and even death. The poisonousness of chromium relates to its chemical formula, with hexavalent chromium (VI) compounds having a toxic, mutagenic and even carcinogenic nature, and the trivalent chromium (III), which occurs in foods having a low toxicity. Acceptance limit of $\mathrm{Cr}$ in milk is $0.3 \mathrm{ppm}$ (Qin et al. 2009). The recommended value for chromium (III) is $50-200 \mu \mathrm{g}$ per day (Belete et al. 2014).

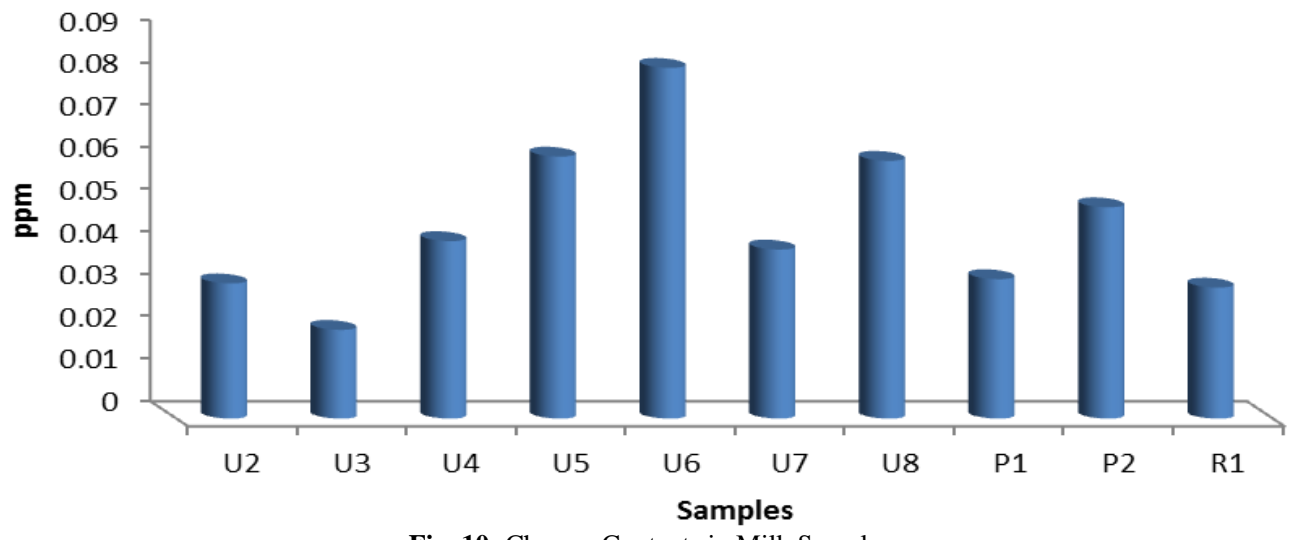

Fig. 10: Chrome Contents in Milk Samples.

\subsection{Lead levels}

From Fig. 11, we notice that the lead content in the studied milk samples ranged from (0.024-0.083 ppm). The highest concentration was in sample U3, while the lowest was in sample R1. The concentrations of Pb in Krishna et al. (2015) study for long life and pasteurized milk samples were in the ranges $0.0442-0.0575 \mathrm{ppm}$ which were comparable to the present study. The Pb contents of Italian fresh milk samples were reported to be 0.0095 ppm which is lower than our results. Also, the results of Rodriguez et al. (2001) for the determination of fresh cow milk were in Spain lower than the present study. The level of lead in our current study was higher than the FAO / WHO limit $(0.0205 \mathrm{ppm})$. The occurrence of $\mathrm{Pb}$ in milk and dairy products may be as a result of environmental sources (atmospheric deposition, waste disposal, vehicle exhausts, urban effluent etc.). Lead may have destroying effects on the nervous system of infants. Buildup of lead in bones due to earlier exposure is circulated into the blood along with calcium and excreted into breast milk. Exposure to lead is related with anxiety and depression in adults. Additionally, it harmfully impacts the growth of newborns (Bahmani et al. 2018).

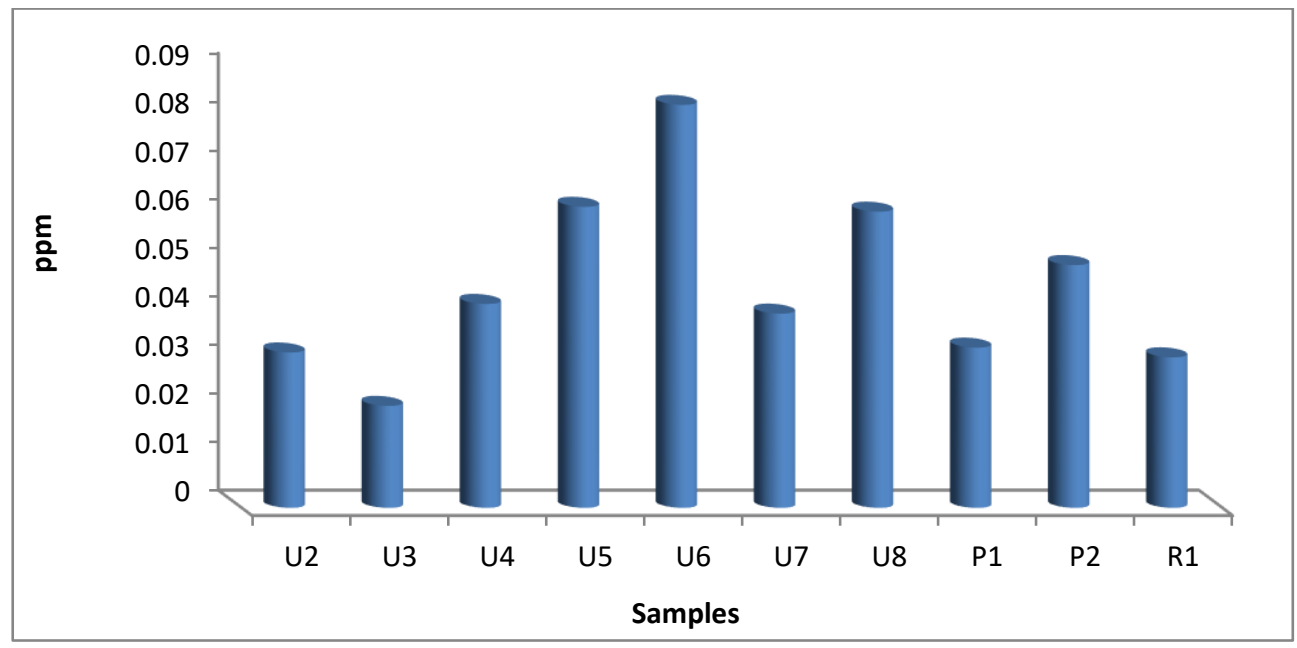

Fig. 11: Lead Contents in Milk Samples.

\subsection{Cobalt and cadmium levels}

In all examined milk samples, the levels of $\mathrm{Co}$ and $\mathrm{Cd}$ were lower than the instrumental detection limits. Milk and eggs have about 0.004- $0.005 \mathrm{ppm}$; dairy products such as cheese and butter are rather rich in cobalt $(0.02 \mathrm{ppm})$. Eggs and milk comprise even larger quantities of vitamin B12 irrelevant cobalt (about 70 and $95 \%$, respectively) demonstrating excretion of absorbed soluble cobalt (Scientific Opinion 2009). The occurrence of $\mathrm{Cd}$ in milk and dairy products may be owing to either natural or anthropogenic sources (fertilizers and atmospheric deposition in soils). It is regard as the most critical pollutant in current days. $\mathrm{Cd}$ and $\mathrm{Pb}$ are among the metals that have affected the most concern in terms of undesirable effects on human health. This is because they are easily transported through food chains and are not known to provide any fundamental biological function (Arafa et al. 2014). 


\section{Conclusion}

The current paper provides significant information on the levels of essential $(\mathrm{Na}, \mathrm{K}, \mathrm{Ca}$, and $\mathrm{Mg}$ ) and heavy metals $(\mathrm{Fe}, \mathrm{Zn}, \mathrm{Cu}, \mathrm{Mn}, \mathrm{Cr}$, $\mathrm{Co}, \mathrm{Ni}, \mathrm{Cd}$, and $\mathrm{Pb}$ ) in long life and pasteurized milk samples. For major metals, potassium was the metal detected at highest levels with an average concentration of $828.05 \pm 0.82 \mathrm{ppm}$ followed by calcium with a mean of $587.57 \pm 0.87 \mathrm{ppm}$. While for minor metals, zinc and iron had the highest concentration with an average of: $2.014 \pm 0.19$ and $1.89 \pm 0.16 \mathrm{ppm}$, respectively. Cobalt and cadmium were not detected in all examined milk samples. The outcomes of our study obviously show that the ingesting of milk and dairy products relate to an important quantity of the reasonable daily intake of $\mathrm{K}, \mathrm{Ca}, \mathrm{Na}, \mathrm{Mg}$, and $\mathrm{Zn}$. Fresh milk are poor source of $\mathrm{Fe}, \mathrm{Cu}, \mathrm{Mn}, \mathrm{Cr}$, and $\mathrm{Ni}$. Consumption of fresh milk is approximately free of risks, but bioaccumulation of lead and other heavy metals via the food chain and consumption from other food stuff should also be of interest. More consideration should be provided to heavy metals as once they are occurred in concentrations greater than the acceptable daily intake.

\section{Acknowledgement}

We would like to acknowledge the Chemistry Department at Faculty of Science - Misurata University for providing all facilities to complete this research.

\section{References}

[1] Abdulkhaliq A., Swaileh KM., Hussein RM., Matani M. (2012) Levels of metals (Cd, $\mathrm{Pb}, \mathrm{Cu}$ and $\mathrm{Fe}$ ) in cow's milk, dairy products and hen's eggs from the West Bank, Palestine. International. Food Research. Journal, 19 (3), 1089-1094.

[2] Amponsah D (2014). Determination of levels of heavy metals (arsenic, lead, cadmium and mercury) in tin milk produced in Ghana. International Journal of Advancements in Research and Technology, 3 (6), 129-133.

[3] Arafa MS, Walaa MA, Nour El-Houda M, Hassan Y (2014). Heavy metals and trace elements levels in milk and milk products. Food Measurements, 8, 381-388. https://doi.org/10.1007/s11694-014-9203-6.

[4] Assis AM, Gaudenzi EM, Gomes G, Ribeiro RC, Szarfarc SC, Souza SB (2004). Hemoglobin concentration, breastfeeding and complementary feeding in the first year of life. Revista de Saúde Pública 38, 543-51. https://doi.org/10.1590/S0034-89102004000400010.

[5] Ateteallah, HA and Hassan MF (2017). Assessment of Sodium, Calcium and Potassium in Buffalo's Raw Milk and its Rural Products in some centers of Sohag Governorates. Egyptian Journal Food and Dairy Science, 8 (8), 331-334 https://doi.org/10.21608/jfds.2017.38893.

[6] Bahmani P, Sadeghi S, Ghahremani E, Daraei H (2018). Evaluation of Lead and Cadmium levels in breast milk in Sanandaj, Iran. Journal of Advances Environmental Health Research, 6, 144-151.

[7] Belete T, Hussen A, Rao VM (2014). Determination of Concentrations of Selected Heavy Metals in Cow's Milk: Borena Zone, Ethiopia. Journal Health Science, 4 (5), 105-112.

[8] Birghila S, Dobrinas S, Stanciu G, Soceanu A (2008). Determination of Major and Minor Elements in Milk Through ICP-AES. Environmental Engineering and Management Journal, 7 (6), 805-808. https://doi.org/10.30638/eemj.2008.107.

[9] Caballero BH, Catharine, Ross AC, Cousins RJ, Tucker KL, Ziegler TR (2014). Modern Nutrition in Health and Disease, 11th ed., Wolters Kluwer Health Adis (ESP), Baltimore, Lippincott Williams \& Wilkins, pp:238-44.

[10] Casarett, LJ Doull J (2000). The fundamentals of the action of toxic substances, 5th ed., Roma: EMSI.

[11] Cashman KD (2006). Milk minerals (including trace elements) and bone health. International Dairy Journal, 16, 1389-1398. https://doi.org/10.1016/j.idairyj.2006.06.017.

[12] Cava-Montesinos P, Ródenas-Torralba E, Morales-Rubio A, Cervera ML, de la Guardia M (2004). Cold vapour atomic fluorescence determination of mercury in milk by slurry sampling using multicommutation. Analytica Chimica Acta, 506, 145-153. https://doi.org/10.1016/j.aca.2003.11.023.

[13] EFSA Panel on Additives and Products or Substances used in Animal Feed (FEEDAP) (2009). Scientific Opinion on the use of cobalt compounds as additives in animal nutrition. EFSA Journal, 7(12), 1383-1438. https://doi.org/10.2903/j.efsa.2009.1383.

[14] Elsherif KM, \& Kuss HM (2012). Simultaneous Multielement determination of bismuth (Bi), antimony ( $\mathrm{Sb}$ ) and selenium (Se). Advances in Applied Science Research, 3, 2402-2412.

[15] Elsherif KM, Abu Khater RA, Hegaig FA (2017). Determination of major and minor elements in dairy products produced in Misurata city - Libya Maghrebian Journal of Pure \& Applied Science, 3 (2), 09- 17.

[16] Elsherif KM, Benkhayal AA, and Kuss HM (2013). Rapid and Direct Determination of Bi, Sb, and Cd in Biological Samples by Multi-Element Graphite Furnace Atomic Absorption Spectrometer. Elixir Applied Chemistry, 64, 19165-19169.

[17] Elsherif KM, Kuss HM (2012). Direct and simultaneous determination of bismuth, antimony, and lead in biological samples by multi-element Electrothermal atomic absorption spectrometer. Der Chemica Sinica, 3, 727-736.

[18] Enb A, Abou Donia MA, Abd-Rabou NS, Abou-Arab AAK, and El-Senaity MH (2009). Chemical Composition of Raw Milk and Heavy Metals Behavior During Processing of Milk Products. Global Veterinaria, 3(3), 268-275.

[19] European Union Risk Assessment Report (2008). Nickel risk assessment, Prepared by the Danish Environmental Protection Agency for the European Union, 1-1715.

[20] Farid SM, Enani MA, and Wajid SA (2004). Determination of Trace Elements in Cow's Milk in Saudi Arabia. Journal of King Faisal University: Engineering Science, 15 (2), 131-140. https://doi.org/10.4197/Eng.15-2.9.

[21] Flynn A (1992). Minerals and trace elements in milk. Advances in Food and Nutrition Research, 36, 209-252. https://doi.org/10.1016/S10434526(08)60106-0.

[22] Gabryszuk M, Słoniewski K, and Sakowski T (2008). Macro- and microelements in milk and hair of cows from conventional vs. organic farms. Animal Science Papers and Reports, 26 (3), 199-209.

[23] Gaucheron F (2005). The minerals of milk. Reproduction Nutrition Development, 45 473- 483. https://doi.org/10.1051/rnd:2005030.

[24] Goncalves JR, Mesquita AJ, and Goncalves RM, (2008). Determination Heavy metal.s in pasteurized whole bovine milk in state of Goias. Ciencia Animal Brasil, 9, 365-374.

[25] Hadler MC, Colugnati FA, Sigulem DM (2004), Risks of anemia in infants according to dietary iron density and weight gain rate, Prev Med., 39, 713-21. https://doi.org/10.1016/j.ypmed.2004.02.040.

[26] Institute of Medicine (US) Panel on Micronutrients (2001), Dietary Reference Intakes for Vitamin A, Vitamin K, Arsenic, Boron, Chromium, Copper, Iodine, Iron, Manganese, Molybdenum, Nickel, Silicon, Vanadium, and Zinc, National Academies Press (US), Washington (DC).

[27] Khan ZI, Ahmad K, Bayat A, Mukhtar MK, Sher M (2013) Evaluation of lead concentration in pasture and milk: A possible risk for livestock and public health. Pakistan Journal of Zoology., 45 (1), 79-84.

[28] Kira CS and Maihara VA (2007). Determination of major and minor elements in dairy products through inductively coupled plasma optical emission spectrometry after wet partial digestion and neutron activation analysis. Food Chemistry, 100, 390-395. https://doi.org/10.1016/j.foodchem.2005.09.014.

[29] Krishna GA, Al aamri MA, Al Kinde HS, Al aamri KE, and Dedi CK (2015). Proximate and Mineral Compositions (major and minor elements) of Commercial, Cattle's Raw Milk \& Dairy Products. International Journal of Inorganic and Bioinorganic Chemistry, 5 (1), 19-22. 
[30] Lante A, Lomolino G, Cagnin M, and Spettoli P (2004). Content and characterisation of minerals in milk and in Crescenza and Squacquerone Italian fresh cheeses by ICP-OES. Food Control, 17(3), 229-233. https://doi.org/10.1016/j.foodcont.2004.10.010.

[31] Licata P, Trombetta D, Cristani M, Giofre F, Martino D, Calo M, and Naccari F (2004). Levels of toxic and essential metals in Samples of bovine milk From Various dairy farms in calabria, ltaly. Environmental International, 30, 1-6. https://doi.org/10.1016/S0160-4120(03)00139-9.

[32] Lutfullah G, Abid Khan A, Amjad AY, and Perveen S (2014). Comparative Study of Heavy Metals in Dried and Fluid Milk in Peshawar by Atomic Absorption Spectrophotometry. Science World Journal, 2014, 1-5. https://doi.org/10.1155/2014/715845.

[33] Malbe M., Otstavel T, Kodis I, and Viitak A (2010). Content of selected micro and macro elements in dairy cows' milk in Estonia. Agronomy Research (Special Issue II), 8, 323-326.

[34] Malhat F., Hagag M., Saber A., and Fayz A.E (2012). Contamination of Cows Milk by Heavy Metal in Egypt. Bulletin of Environmental Contamination and Toxicology, 88, 611-613. https://doi.org/10.1007/s00128-012-0550-X.

[35] Marcio ARS, da Silva IF (2016). Sodium, Potassium and Other Essential Mineral Contents on Dairy Milk Available in the Markets of a Northeastern Capital in Brazil: A Sodium Intake Estimation for Children. Food and Public Health, 6 (6), 165-173.

[36] Michaelsen K, Weaver LT, Branca F, Robertson A (2000). Feeding \& nutrition of infants \& young children. WHO Regional Publications, No. 87, Copenhagen, Denmark.

[37] Moreno R, Amaro MA, and Zurera G (1994). Mineral content in Spanish sterilized milk. Food Science and Technology International, $34,323-332$.

[38] Najah Z, Elsherif KM, Alshtewi M, Attorshi H (2015). Phytochemical Profile and Heavy Metals Contents of Codium Tomentosum And Sargassum Hornschuchi. Journal of Applicable Chemistry, 4(6), 1821-1827.

[39] Nasr IN, Sailam AA, and Abd El- Khair AA (2007). Monitoring of Certain pesticidues residues and some heavy metals in Fresh Cow's milk at gharbia govern orate, Egypt. Journal of Applied. Science, 7 (20), 3038-3044. https://doi.org/10.3923/jas.2007.3038.3044.

[40] Ogabiela EE, Udiba UU, Adesina OB, Hammuel C, Ade-Ajayi FA, Yebpella GG, Mmereole UJ, and Abdullahi. (2011). Assessment of Metal Levels in Fresh Milk from Cows Grazed around Challawa Industrial Estate of Kano, Nigeria. Journal of Basic and Applied Science Research, 1(7), 533-538.

[41] Oliveira MAA, Osório MM (2005). Cow’s milk consumption and iron deficiency anemia in children. Jornal de Pediatria, 81 (5), $361-367$. https://doi.org/10.2223/JPED.1386.

[42] Onianwa PC, Adetola IG, Iwegbue CMA, Ojo MF, and Tella OO (1999). Trace heavy metals composition of some Nigerian beverages and food drinks. Food Chemistry, 66, 275-279. https://doi.org/10.1016/S0308-8146(98)00257-X.

[43] Qin LQ, Wang XP, Li W, Tong X, Tong WJ (2009). The minerals and heavy metals in cow's milk from China and Japan. Journal of Health Science, 55 (2), 300-305. https://doi.org/10.1248/jhs.55.300.

[44] Rodriguez R, Sanz EM, Alaejos M, and Diaz RC (2001). Mineral concentrations in cow's milk from the Canary Island. Journal Food Composition Analalysis., 14, 419- 430. https://doi.org/10.1006/jfca.2000.0986.

[45] Sola-Laranaga C and Navarro-Blasco I (2009). Chemometric analysis of minerals and trace elements in raw cow milk from the community Navarra. Spain. Food Chemistry, 112, 189-196. https://doi.org/10.1016/j.foodchem.2008.05.062.

[46] Suarez-Luque S, Mato I, Huidobro JF, Simal-Lozano J (2007). Determination of major metal cations in milk by capillary zone electrophoresis. International Dairy Journal, 17, 896-901. https://doi.org/10.1016/j.idairyj.2006.12.004.

[47] Tajkarimi M., Faghih MA, Poursoltani H, Nejad AS, Motallebi AA, Mahdavi H (2008). Lead residue levels in raw milk from different regions of Iran. Food Control, 19, 495-498. https://doi.org/10.1016/j.foodcont.2007.05.015.

[48] Zheng N, Wang Q, Zhang X, Zheng D, Zhang Z, Zhang S (2007). Population health risk due to dietary intake of heavy metals in the industrial area of Huludao city. China, Science of the Total Environment, 387, 96-104. https://doi.org/10.1016/j.scitotenv.2007.07.044. 